\title{
Design of an operations manager selection system in service encounter
}

\author{
Tanawin Nunthaphanich and Natcha Thawesaengskulthai*
}

Industrial Engineering, Chulalongkorn University, Bangkok, Thailand

\begin{tabular}{l}
\hline C H R O N I C L E \\
\hline Article history: \\
Received March 25, 2015 \\
Received in revised format \\
August 62015 \\
Accepted August 62015 \\
Available online \\
August 92015 \\
\hline Keywords: \\
Operations management \\
Operations manager selection \\
Service encounter \\
Analytical hierarchy
\end{tabular}

\section{A B S T R A C T}

The purpose of this study is to provide criteria for selecting operations managers at the 'service encounter' for mobile telecommunication companies, and develop a system for this multicriteria decision-making scheme based on the Analytical Hierarchy Process (AHP). There are three main criteria for evaluating the capability of service-encounter operation managers: (1) the ability to design service process; (2) the ability to operate service process; (3) the ability to conduct improvement. The AHP operation manager selection tool was developed based on the complex problems at the service encounter. It was created as a decision support system which was used to recruit and evaluate operations managers' capability for the purpose of career advancement.

\section{Introduction}

Recently, there has been intense competition in the market share among well-known telecommunication companies. One of the most important factors in people selecting a vendor is the quality of service at the service encounter. It is a direct communication between the service encounter and customers, and effective operations management at the service encounter enhances company's competitiveness. Common problems found at a poor service encounter are complaints from unsatisfied customers, caused by having to wait in line for too long on average. The main reason for this problem stems from the operations managers with poor management abilities, resulting in ineffective problemsolving skills.

The in-depth knowledge of operations management is not only applicable for the manufacturing industry but also profitable for the service industry (Johnston, 1999). In general, there are nine areas of the service industry that can benefit from applying operation management. These are: linking operation's performance to business drivers, performance measurement and operations improvement,

\footnotetext{
* Corresponding author.

E-mail address: natcha.t@chula.ac.th (N. Thawesaengskulthai) 
guarantees, complaints and service recovery, managing people, service design, service technology, the design of internal networks, the service encounter, and managing service capacity (Johnston, 2005). Moreover, the Customer Operations Performance Center (COPC) - a guideline to management practices, key measurements, and training for customer-centric service operations is designed to improve customer satisfaction through improving the service and quality, increasing revenue, and reducing the cost of providing excellent service.

There are three criteria for selecting the best adequate personnel (Güngör et al., 2009). The first criterion is the general work factor including work experience, the use of foreign languages, bachelor's degree, master's degree, analytical thinking, and basic computer skills. Second, the complimentary work factor is composed of decision making, team working, effective time management, willingness, lifelong learning, and determination to meet objectives and goals. The last criterion is the individual factor that consists of core ability, appearance, age, culture, and written communication skill. Although employees who have passed these three criteria are able to do routine tasks at the service encounter, they cannot handle the operational problems effectively, especially when an unusual situation happens. This is because the employee lacks of operations management abilities. Therefore, this study will focus on selecting the most capable operations manager at the service encounter in order to improve the service quality. The ultimate goal of this research is to identify the multi-criteria for selecting an operations manager who can manage the operational work efficiently with the purpose of recruiting or promoting employees to a higher operations management position.

Among the several tools for multi-decision making, Analytical Hierarchy Process (AHP) is considered as the most attractive one to select the best alternative since AHP does not limit the number of criteria and alternatives. So that, all criteria as well as alternatives can be performed with Pairwise comparison which is the most precise method in prioritizing criteria and candidates (Peniwati, 2007). AHP is a structured technique that helps decision makers to find the decision that best suits their goal and their understanding of the problem. It provides a comprehensive and rational framework for structuring decision problems, representing and quantifying its elements, relating those elements to overall goals, and evaluating alternative solutions (Saaty, 1980). In this study, the first level of the hierarchy is selecting the most suitable operations manager. The second level is the main operations management criteria, which is used for selecting an operations manager. The third level specifies sub-criteria which are related to the criteria in the second level. The bottom level of the hierarchy includes the candidates to be evaluated. This hierarchy is summarized in Fig. 1.

\section{Methodology}

Research methodology in this study is divided into four phases as shown in Fig. 2. The multiple criteria to determine an eligible operations manager is explored and established in the first phase. After this, phase two leads the multiple criteria from the first phase and develops it to test operations management candidates. Next, in phase three, the qualitative data received from the tests are analyzed by using AHP tools and sensitivity analysis. Phase four provides decision support system to help users reduce frustration of AHP model.

\section{First phase: establishing the multiple criteria for selecting operations}

The multiple criteria for evaluating operations management capabilities are established, and the relevant literature about operations management in textbooks, journal and COPC standard was reviewed (Machuca et al., 2007; Fitzsimmons, 2011; Russell \& Taylor, 2011; Slack et al., 2010). In addition, an in-depth mobile telecommunications service provider in Thailand with a number of service encounters was investigated in order to identify the main problems that usually occur in the working situation. Problems in the service encounter were observed and classified into two main groups. The first group is customer complaint problems while the second one is the problems in service operations. 
Problems from customer complaints during year 2012 to 2013 are pointed out in the questionnaire of over 5,000 customers. In order to point out the problems in service encounter with impact to customer satisfaction, these questionnaires are open-ended questionnaire which distributed the several complaints from customer.

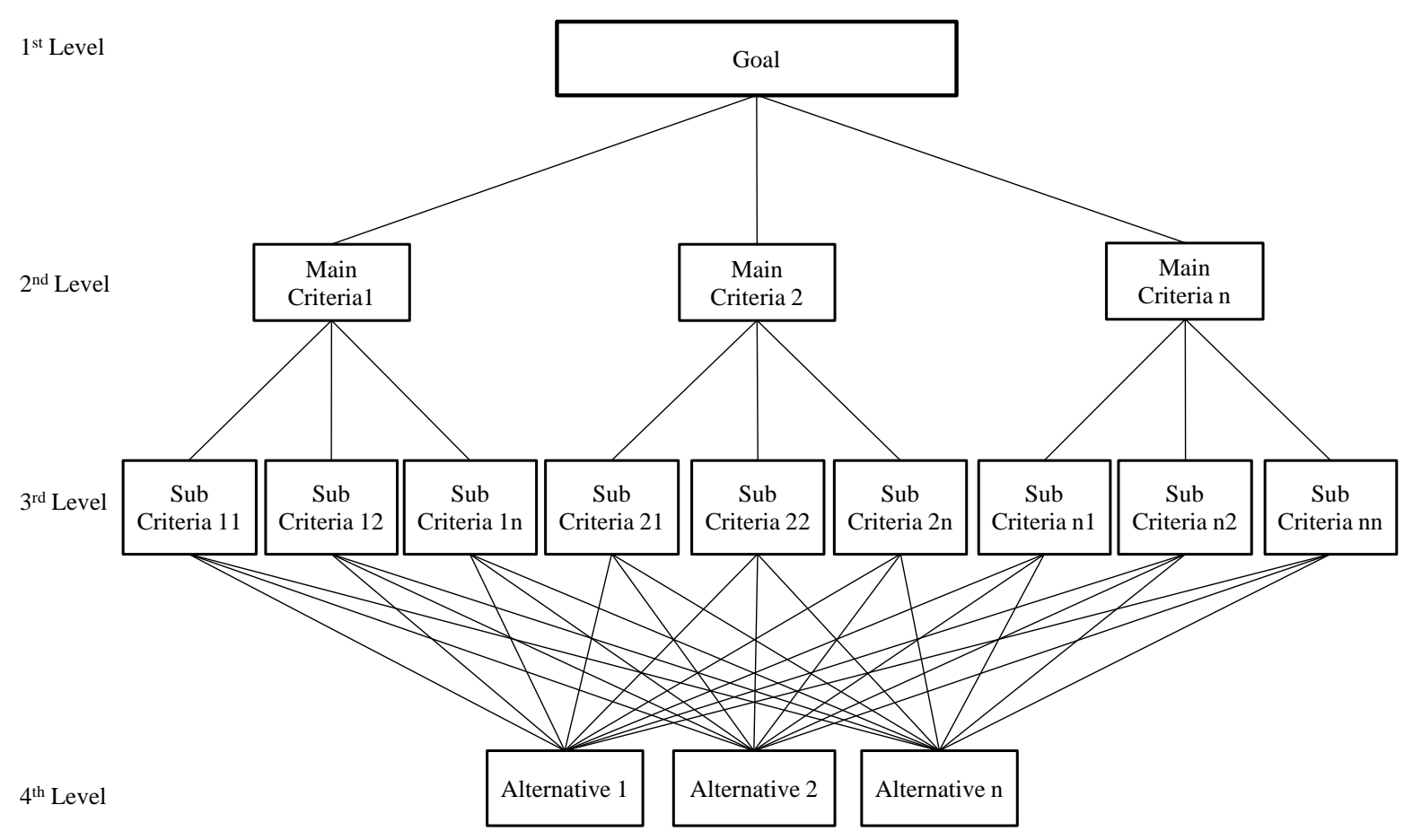

Fig. 1. The hierarchy of AHP method.

Using Pareto analysis, there are five problems that occupied over 80 percent of this group. The poor environment at the service encounter is the most claimed problem followed by inconveniences during the service provision, the average amount of time a customer spends waiting in line being too long, lack of customer care, and insufficient service supporting facilities. The result is illustrated in Fig. 3.

In the second group, the problems are specified based on focus group interviews with experienced managers at service encounters in a case company. Problems which were obtained from interviews are summarized in three main categories. The first category is customer service failure that was caused by staff not following specified service standards or procedures. Second, when problems occurred at the service encounter, the operations manager could not find the root cause of the problem and was unable to solve it effectively. Finally, there is no risk management plan to aid operations from unexpected serious events such as natural disasters, burglary, fire, or other serious events.

Once problems from both customer complaints and managers were clearly identified, group interviews with managers were then conducted in order to investigate the root causes of these problems. The major cause is the lack of operational management abilities/experience in the service manager. Therefore, the service encounter cannot provide a good service. Operations management knowledge areas were then shared with service operations managers in order to improve these operational services. The suggested operations management techniques to be used for these operational problems are shown in Table 1. 


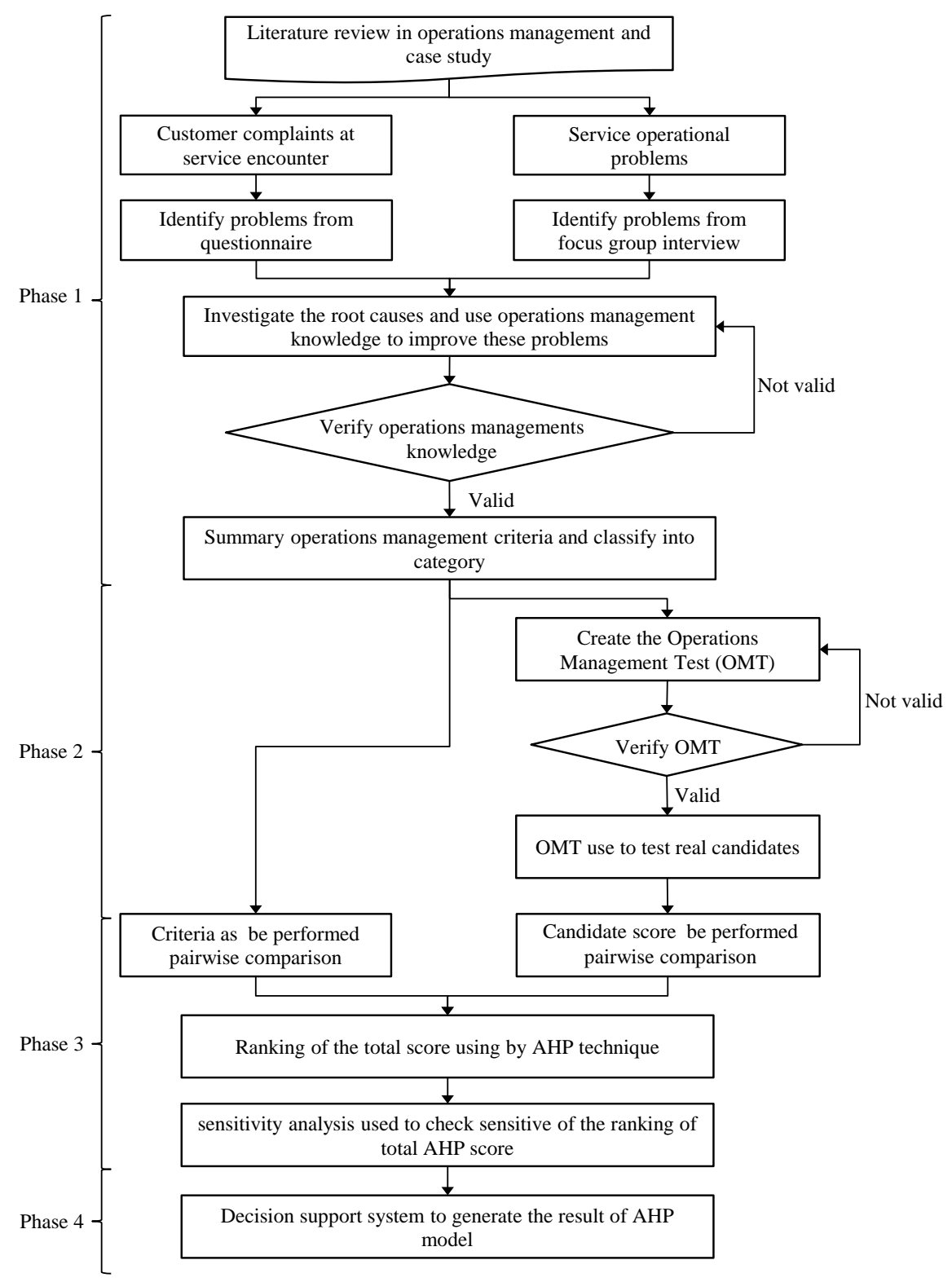

Fig. 2. Research methodology.

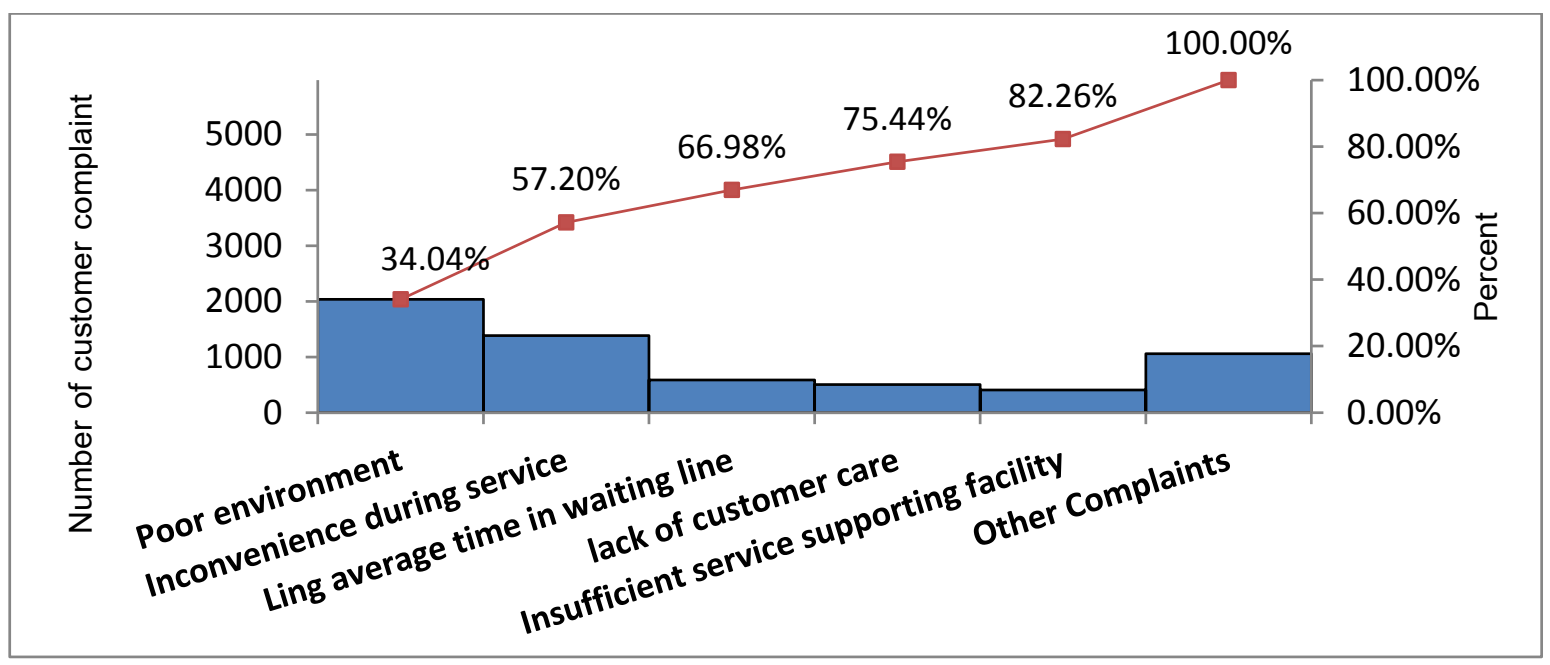

Fig. 3. Pareto chart of customer complaint at service encounter 
Table 1

Operations management knowledge to solve the identified operations problems

\begin{tabular}{|c|c|}
\hline Problem & Operations management techniques \\
\hline $\begin{array}{l}\text { The poor environment at the service } \\
\text { encounter }\end{array}$ & 1. Supporting facility with design layout and facility for encounter \\
\hline Inconvenience during service & $\begin{array}{l}\text { 2. Application of SERVQUAL to measure the communication gap } \\
\text { between customer and service delivery. }\end{array}$ \\
\hline \multirow{4}{*}{$\begin{array}{l}\text { Too long average time customer spends } \\
\text { waiting in line }\end{array}$} & 3. Managing waiting lines to establish a queue structure. \\
\hline & 4. Scheduling a process of work for the staff. \\
\hline & $\begin{array}{l}\text { 5. Capacity planning to measure effectiveness and to find the bottle neck } \\
\text { of the service process. }\end{array}$ \\
\hline & 6. Lean system method to eliminate the waste of the service process. \\
\hline Lack of customer care & $\begin{array}{l}\text { 7. People, job, and organization to create staff training and teamwork to } \\
\text { improve customer care. }\end{array}$ \\
\hline Insufficient service supporting facility & $\begin{array}{l}\text { 8. Inventory management to set order quantity and safety stock for } \\
\text { products }\end{array}$ \\
\hline $\begin{array}{l}\text { Customer service failure caused by staff who } \\
\text { do not follow specified service standards or } \\
\text { procedures }\end{array}$ & $\begin{array}{l}\text { 9. Quality in service with quality assurance and auditing to check } \\
\text { compliance of staff }\end{array}$ \\
\hline $\begin{array}{l}\text { The operations manager cannot find the root } \\
\text { causes of the problems and was unable to } \\
\text { solve it effectively }\end{array}$ & $\begin{array}{l}\text { 10. Improving operations by using QC } 7 \text { tools technique to find the root } \\
\text { cause of the problem and use other techniques to solve it }\end{array}$ \\
\hline $\begin{array}{l}\text { No risk management plan in the event of } \\
\text { unexpected serious events }\end{array}$ & $\begin{array}{l}\text { 11. Risk management to assess the risks that may occur and action to } \\
\text { prevent them. }\end{array}$ \\
\hline
\end{tabular}

After operations management techniques from a literature review were selected and matched with the service problems, Item-Objective Congruency index (IOC) questions were constructed and presented to operations management experts (1 person of industrial engineering academician, 3 people of senior and top-level managers at the case company) to verify the matching results. Each subject question was rated on three scales: '- 1 ' represented disagree, ' 0 ' represented not assured, and ‘ +1 ' represented agree. The IOC index from all questions were $0.841(n=4)$ which illustrates the suitable level of content validity (IOC index must be more than 0.5 ). The mention formula for calculating IOC index are shown in Table 2.

Based on the IOC results, verified operations management techniques were considered as criteria which had been used in this project. All criteria were then classified into three main categories which are 1) the ability to design a service process, 2) the ability to operate a service process, and 3) the ability to conduct improvement based on the operations management textbook (Slack et al., 2010). Each main criterion has its own sub criteria. All criteria are summarized in Fig. 4.

\section{Second phase: leading the multiple criteria into test with operations manager candidates}

According to the results from phase one, ten identified sub-criteria were used to create the Operations Management Test (OMT). OMT is a five multiple-choice question that contains the total of 44 questions (four questions per one sub criterion) and the examinees were asked to give answers within 2 hours. These questions aim to test the general operational management concepts of the candidate, and also to see the way they handle problems found at the service encounter that have been given.

To test the validity of this exam, OMT had been used to test the applicants who wished to pursue the Industrial Engineering Master's program at Chulalongkorn University. All applicants have experiences in industry and strong motivation to join the program which is similar to the candidates at the case company that have service operation background and would like to be promoted to a higher position in operations. The entrance exam scores in relation to the number of years of experience in industry. This is displayed in Fig. 5. It clearly shows that candidates with longer working experience gain higher scores than the lower one (correlation coefficient $=0.8434$ ). The $\mathrm{R}$-square value is more than 0.7 which 
indicates that the pretest result is valid. Moreover, comparing the academic background of the candidates with the entrance exam scores, the correlation results show that students with an Industrial Engineering background acquire better results than those from other science-based academic background including other branches of engineering. The result shows that T-test (data is normal distribution) is significant ( $\mathrm{p}$-value $=0.025$ ). However, F-test is not significant ( $\mathrm{p}$-value $=0.793$ ). After the OMT was validated by the entrance exam of the Industrial Engineering Master's program, it was then given to the actual ten candidates who worked in the service encounter and had potential to be operations managers. OMT scores from these candidates will be put into the Pairwise comparison method in every criterion by AHP tools in the next phase.

\section{Table 2}

Formula for calculating IOC index. (E1 - E3 are represent to senior and top-level managers at the case company, A1 is represent to industrial engineering academician)

\begin{tabular}{|c|c|c|c|c|c|c|}
\hline \multirow{2}{*}{ Problem } & \multirow{2}{*}{ Operations management techniques } & \multicolumn{4}{|c|}{ Evaluation results } & \multirow{2}{*}{ Avg. } \\
\hline & & E1 & E2 & E3 & A1 & \\
\hline $\begin{array}{l}\text { The poor environment at the service } \\
\text { encounter }\end{array}$ & $\begin{array}{l}\text { 1. Supporting facility with design layout } \\
\text { and facility for encounter }\end{array}$ & 0 & +1 & 0 & +1 & 0.50 \\
\hline Inconvenience during service & $\begin{array}{l}\text { 2. Application of SERVQUAL to } \\
\text { measure the communication gap } \\
\text { between customer and service delivery. }\end{array}$ & +1 & +1 & 0 & +1 & 0.75 \\
\hline \multirow[t]{4}{*}{$\begin{array}{l}\text { Too long average time customer } \\
\text { spends waiting in line }\end{array}$} & $\begin{array}{l}\text { 3. Managing waiting lines to establish a } \\
\text { queue structure. }\end{array}$ & +1 & +1 & +1 & +1 & 1.00 \\
\hline & $\begin{array}{l}\text { 4. Scheduling a process of work for the } \\
\text { staff. }\end{array}$ & +1 & +1 & +1 & +1 & 1.00 \\
\hline & $\begin{array}{l}\text { 5. Capacity planning to measure } \\
\text { effectiveness and to find the bottle neck } \\
\text { of the service process. }\end{array}$ & +1 & +1 & +1 & +1 & 1.00 \\
\hline & $\begin{array}{l}\text { 6. Lean system method to eliminate the } \\
\text { waste of the service process. }\end{array}$ & +1 & +1 & +1 & +1 & 1.00 \\
\hline Lack of customer care & $\begin{array}{l}\text { 7. People, job, and organization to create } \\
\text { staff training and teamwork to improve } \\
\text { customer care. }\end{array}$ & 0 & +1 & +1 & 0 & 0.50 \\
\hline $\begin{array}{l}\text { Insufficient service supporting } \\
\text { facility }\end{array}$ & $\begin{array}{l}\text { 8. Inventory management to set order } \\
\text { quantity and safety stock for products }\end{array}$ & +1 & +1 & +1 & +1 & 1.00 \\
\hline $\begin{array}{l}\text { Customer service failure caused by } \\
\text { staff who do not follow specified } \\
\text { service standards or procedures }\end{array}$ & $\begin{array}{l}\text { 9. Quality in service with quality } \\
\text { assurance and auditing to check } \\
\text { compliance of staff }\end{array}$ & +1 & +1 & 0 & +1 & 0.75 \\
\hline $\begin{array}{l}\text { The operations manager cannot find } \\
\text { the root causes of the problems and } \\
\text { was unable to solve it effectively }\end{array}$ & $\begin{array}{l}\text { 10. Improving operations by using QC } 7 \\
\text { tools technique to find the root cause of } \\
\text { the problem and use other techniques to } \\
\text { solve it }\end{array}$ & +1 & +1 & +1 & +1 & 1.00 \\
\hline $\begin{array}{l}\text { No risk management plan in the } \\
\text { event of unexpected serious events }\end{array}$ & $\begin{array}{l}\text { 11. Risk management to assess the risks } \\
\text { that may occur and action to prevent } \\
\text { them. }\end{array}$ & 0 & +1 & +1 & +1 & 0.75 \\
\hline Average Scores & & & & & & 0.841 \\
\hline
\end{tabular}

\section{Third phase: analyzing by using AHP tools}

In this phase, all criteria from phase one and the OMT results from phase two were put into the Pairwise comparison (by the well-known Analytical Hierarchy Process or AHP) in order to rank all candidates and select the best candidate to be a service manager. The developed AHP program based on an Excel spreadsheet format is used to implement Pairwise comparison. This was divided into four main steps. 


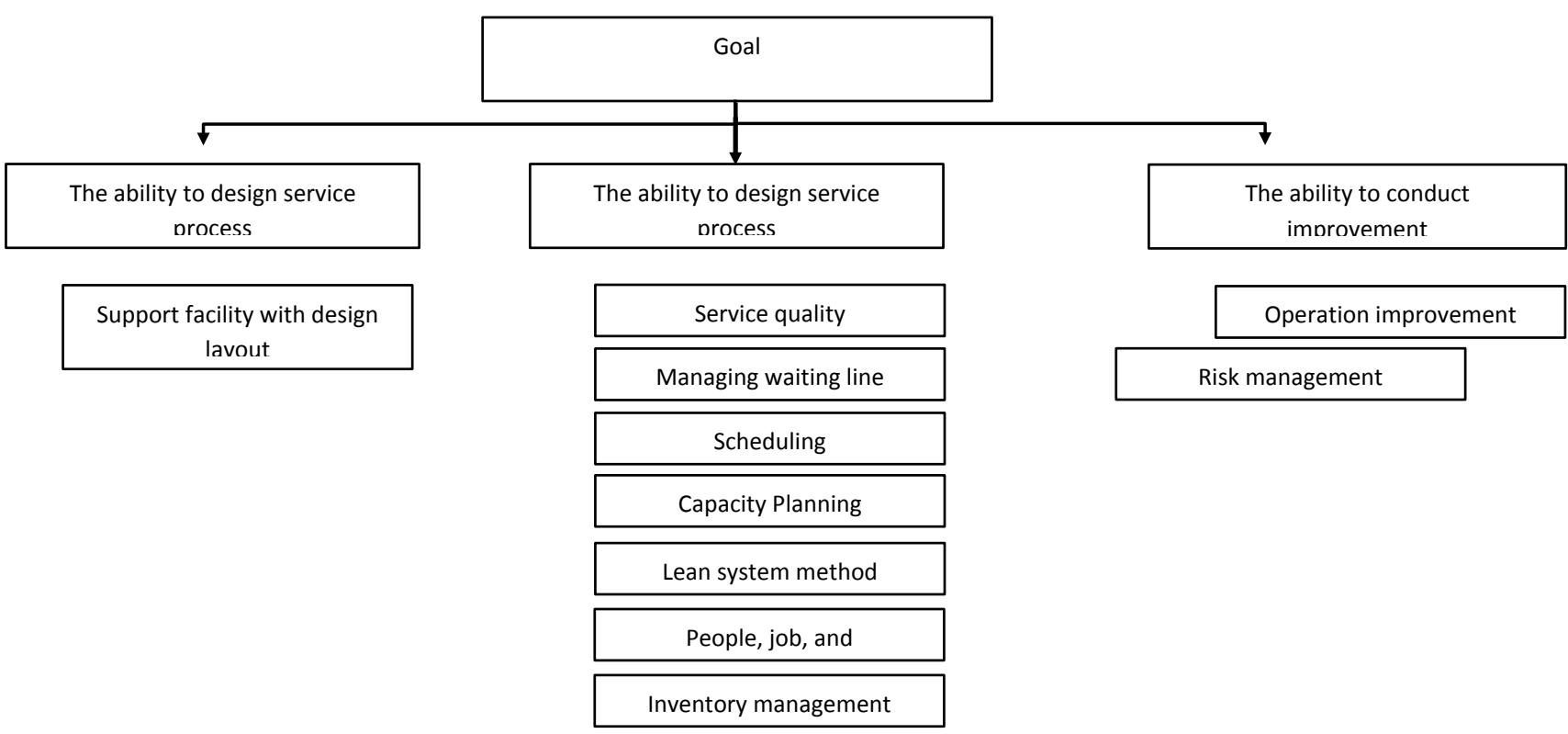

Fig. 4. Hierarchy for operations manager selection problem

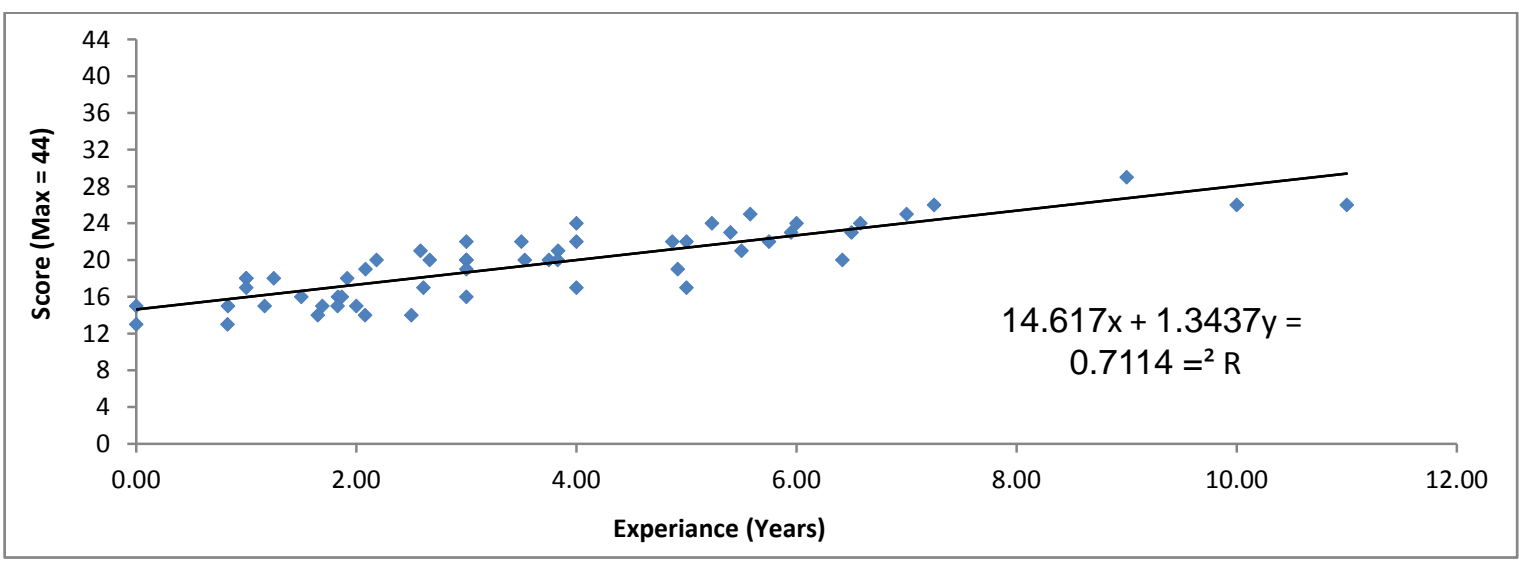

Fig. 5. Pre-test score results of students who pursue the Industrial Engineering master program

\subsection{The first step: pairwise comparison for criteria}

First of all, all criteria were given a rating score and compared to each other in pairs (i.e. four criteria were grouped into 4C2 or 6 pairs). Then the weighting priority value for each criterion was calculated by the AHP method. After that, sub criteria were compared and computed with the priority value by the same method. Weighting priority values for each criterion by top management at service encounter in this study are listed in Table 3.

\subsection{Second step: pairwise comparison for alternatives}

In step two, results from the OMT were performed with pairwise comparison. Then, the weighting values for OMT scores from all candidates were calculated using the AHP method again. Weighting priority values for each candidate are shown in Table 4.

\subsection{Third step: AHP calculation}

In step three, the total scores for each candidate were calculated by summing the product between weighting global priority values of each criterion (from step 1) and weighting values of the OMT score 
of each criterion (from step 2). Finally, the total scores were ranked from the highest to the lowest and the candidate that had the highest score was selected to be an operations manager at the service encounter. Ranking of the total scores are illustrated in Table 5.

\subsection{Last step: Sensitivity analysis}

In the last step, a sensitivity analysis was used to check the sensitivity of the ranking of the total AHP score. Through increasing or decreasing the weight priority of criteria, the resulting AHP score changes the priorities and the ranking of the candidates can be observed if changing in the weight priority of criteria happens. The sensitivity analysis of this AHP outcome into performance sensitivity is displayed in Fig. 6.

Table 3

Weighting priority values for each criterion

\begin{tabular}{lllll}
\hline \multirow{2}{*}{ Main Criteria } & $\begin{array}{l}\text { Main } \\
\text { Priority }\end{array}$ & Sub Criteria & $\begin{array}{l}\text { Local } \\
\text { Priority }\end{array}$ & Global Priority \\
\hline \multirow{2}{*}{ Design service process (DS) } & \multirow{2}{*}{0.074} & Design Layout (DL) & 1.000 & 0.074 \\
& & Inconsistency ratio = 0.000 & & \\
\hline & & Service quality (SQ) & 0.043 & 0.028 \\
& & Managing waiting line (MWL) & 0.230 & 0.148 \\
& & Scheduling (SC) & 0.124 & 0.080 \\
Operate service process (OS) & \multirow{2}{*}{0.643} & Capacity planning (CP) & 0.170 & 0.110 \\
& & Lean system method (LSM) & 0.068 & 0.044 \\
& & People, Job, and organization (P) & 0.264 & 0.170 \\
& & Inventory management (IM) & 0.100 & 0.064 \\
\hline \multirow{2}{*}{ Conduct improvement (CI) } & \multirow{2}{*}{0.283 Inconsistency ratio = 0.094 } & & 0.141 \\
& & Operations improvement (OI) & 0.500 & 0.141 \\
\hline Inconsistency ratio $=0.056$ & & Risk management (RM) & 0.500 & \\
\hline
\end{tabular}

Table 4

Weighting priority values for each candidate in each criterion

\begin{tabular}{l|c|ccccccc|crcr}
\hline \multicolumn{1}{c}{ Candidates } & $\begin{array}{c}\text { DS } \\
\text { DL }\end{array}$ & SQ & MWL & SC & CP & LSM & P & IM & OI & RM \\
\hline Candidate 1 & 0.076 & 0.147 & 0.282 & 0.074 & 0.057 & 0.122 & 0.087 & 0.024 & 0.100 & 0.229 \\
Candidate 2 & 0.188 & 0.025 & 0.087 & 0.187 & 0.163 & 0.027 & 0.022 & 0.107 & 0.024 & 0.229 \\
Candidate 3 & 0.188 & 0.147 & 0.087 & 0.030 & 0.021 & 0.027 & 0.282 & 0.367 & 0.024 & 0.065 \\
Candidate 4 & 0.188 & 0.147 & 0.087 & 0.014 & 0.347 & 0.027 & 0.022 & 0.107 & 0.289 & 0.018 \\
Candidate 5 & 0.016 & 0.147 & 0.282 & 0.187 & 0.021 & 0.122 & 0.087 & 0.107 & 0.100 & 0.065 \\
Candidate 6 & 0.188 & 0.013 & 0.022 & 0.187 & 0.057 & 0.122 & 0.282 & 0.107 & 0.024 & 0.065 \\
Candidate 7 & 0.034 & 0.055 & 0.022 & 0.074 & 0.057 & 0.375 & 0.022 & 0.107 & 0.024 & 0.229 \\
Candidate 8 & 0.016 & 0.025 & 0.022 & 0.187 & 0.057 & 0.122 & 0.087 & 0.024 & 0.289 & 0.018 \\
Candidate 9 & 0.034 & 0.147 & 0.022 & 0.030 & 0.163 & 0.027 & 0.022 & 0.024 & 0.100 & 0.065 \\
Candidate 10 & 0.076 & 0.147 & 0.087 & 0.030 & 0.057 & 0.027 & 0.087 & 0.024 & 0.024 & 0.018 \\
\hline
\end{tabular}

In summary of the sensitivity analysis method, the result of AHP methods is much more sensitive to weighting priority of each criterion. In other words, changing weighting values will affect the ranking of the AHP score. Therefore, the weighting priority values should be set carefully.

The grey colored frame shows the interval when the relative importance weight is increased or decreased, the grey colored frame points would change the outcome from decision making in selecting an operations manager to be another one. According to the graph, it was found that the selection criterion of the ability in the service design process had the least amount of change. Therefore, caution should be taken for paired comparison between the service process design ability and other criteria. 
When work teams who performed the selection were interested in selecting another operations manager other than the most appropriate candidate, the decision to select the second candidate could be made. For instance, the first candidate might have greater personality and language abilities which were found in other criteria apart from this research. The executive might make the decision to select the second candidate instead, in order that the feeling could be used in helping make decisions through the procedural analysis process.

\section{Table 5}

Ranking of the total AHP score to select the best operations manager

\begin{tabular}{lll}
\hline Rank & Candidates & AHP Score \\
\hline 1 & Candidate 1 & 0.132 \\
2 & Candidate 4 & 0.125 \\
3 & Candidate 3 & 0.121 \\
4 & Candidate 5 & 0.115 \\
5 & Candidate 6 & 0.112 \\
6 & Candidate 2 & 0.108 \\
7 & Candidate 8 & 0.091 \\
8 & Candidate 7 & 0.082 \\
9 & Candidate 9 & 0.060 \\
10 & Candidate 10 & 0.055 \\
\hline
\end{tabular}

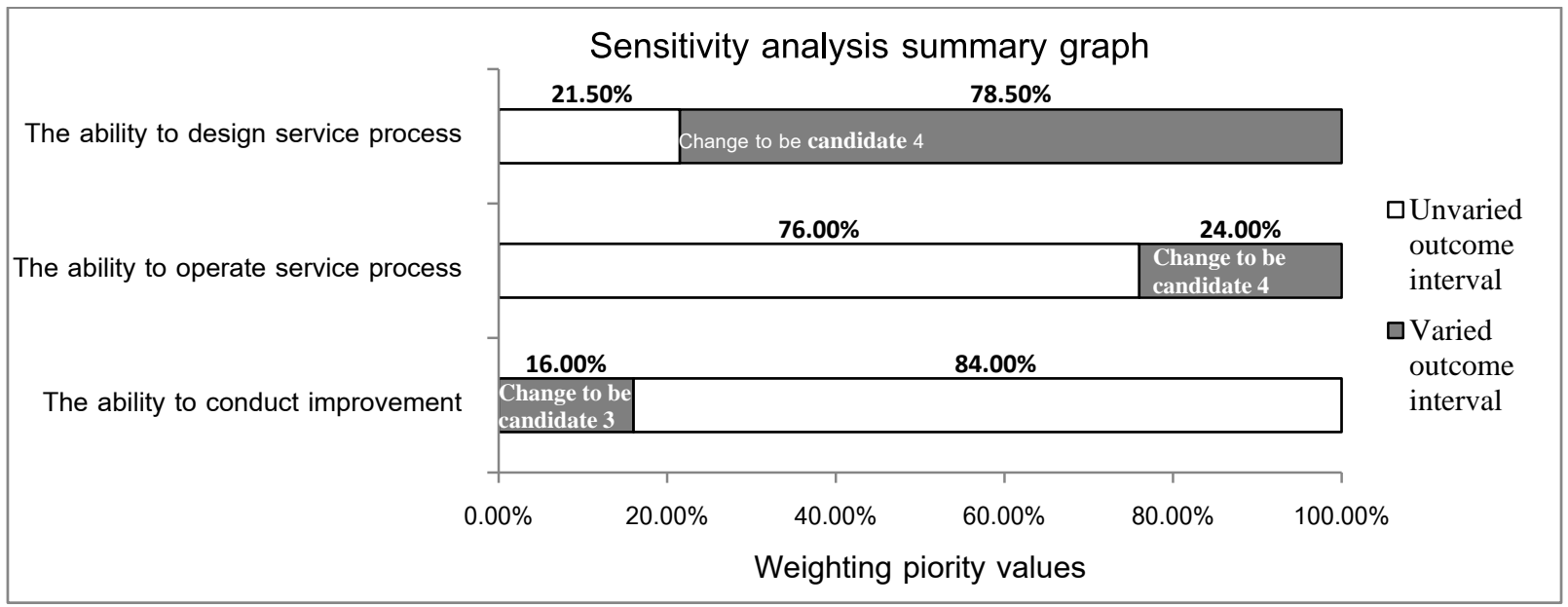

Fig. 6. Sensitivity analysis summary graph

\section{Last phase: decision support system for operations manager selection model}

The supportive system for decision making to select the suitable operations manager is classified into four parts including, processing device (computer), the user applications of decision support systems program (User), decision making model (model), and database. A Personal Computer (PC) with Microsoft Excel 2010 program with the code written for controlling the application software would be chosen as a process device using Visual basic application as the major program in system processing. This would support the decision making for selecting the best operations manager. Since Microsoft Excel 2010 program is the program that all organizations in Thailand use for operations such as data storage, computation and processing, etc. The development of Microsoft Excel 2010 as the supportive system in decision making to select the capable operations manager would help save costs in buying packages and save time in learning the instruction method of these packages. According to the decision support system, the user was the top executive in the position. He or she was involved in selecting the suitable operations manager of the organization for the telecommunication service provision case study. The decision making model would apply a mathematical model of Analytic Hierarchy Process (AHP). The last part of the database would use Excel Spreadsheets from Microsoft Excel 2010 program to store 
information and retrieve data for work processing. The structure of decision support system for selecting a shop operations manager is shown in Fig. 7.

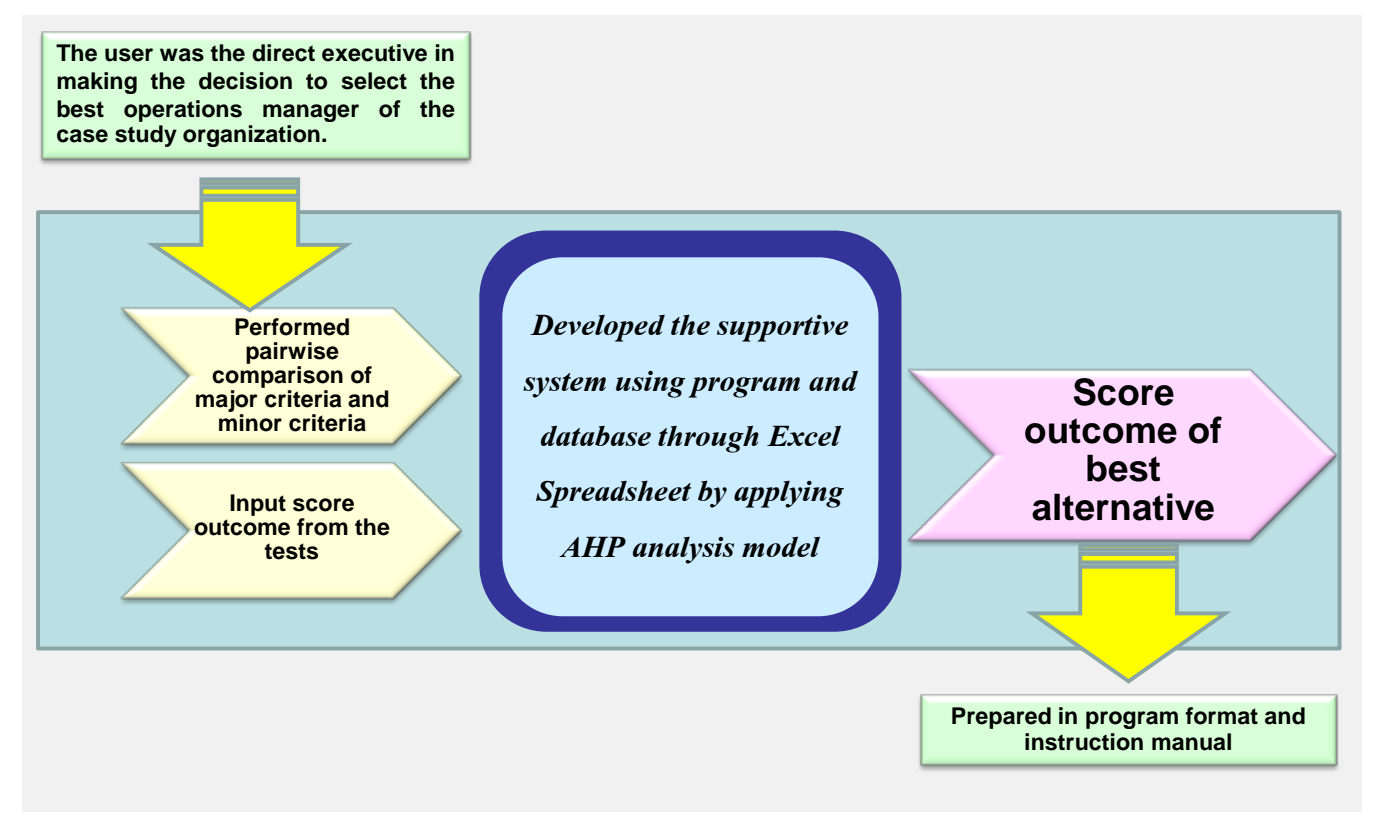

Fig. 7. Decision support system for selecting a shop operations manager

\section{Validity of the decision support system by using AHP method implemented in selecting the suitable operations manager}

In order to make each phase reliable, the researcher used questionnaires for examining the validity of this research. The questionnaires would be given to top executives who were involved in selecting the shop operations manager in the case study organization. The content of the questionnaires would be divided into three main parts including: (1) Feasibility. For the use of criteria in operations management applied in selecting shop operations manager. (2) Usability. For implementing the Analytical Hierarchy Process in selecting the shop operations manager. (3) The decision making model would apply a mathematics model of Analytic Hierarchy Process (AHP).

The finding of the outcomes from the questionnaires satisfied in feasibility at $80.95 \%$, usability at $81.90 \%$, and utility at $81.90 \%$, and the total score was $81.58 \%$. It was concluded that the implementation of Analytical Hierarchy Process for selecting the capable operations managers was valid.

\section{Conclusion}

The objective of the research was to create an instrument for selecting competent knowledgeable personnel in operations management to be operations managers and provide services to the customers in the telecommunication service business of the case study organization. The research classified the operating procedures into four phases: the first phase is the investigation of the criteria for selecting a service operations manager, the second phase is to develop a test of service operations management, the third phase is to design a decision model using Analytic Hierarchy Process for multiple criteria decision making and sensitivity analysis to suggest the most competent and knowledgeable candidate in operations management applied to solve the existing problems which have occurred within the shop division, and the fourth phase provides the result from the developed decision support system which suggests the promising shop operations manager. Finally, this developed decision support system is tested for its reliability and validity by the questionnaires regarding its feasibility, usability, and utility 
of this research. They were given to top executives who were involved in selecting the suitable operations manager in the case study. The result is shown that the operations manager selection system by the AHP model is accurate and can be applied to assist selecting operations managers in service encounter applications.

\section{Acknowledgements}

This research was supported research funding from the $90^{\text {th }}$ anniversary of Chulalongkorn University. And the authors are so grateful to get much valuable information from managers and experts who work at service encounter in the famous telecommunication service corporation in Thailand

\section{References}

Bahurmoz, A. M. A. (2003). The Analytic Hierarchy Process at Dar Al-Hekma, Saudi Arabia. Interfaces, 33(4), 70-78.

Coughlan, P., \& Coghlan, D. (2002). Action research for operations management. International Journal of Operations and Production Management. 22(2), 220-240.

COPC-2000® CSP Standard. (2011). http://www.copc.com/certification/

Dyer, R.F., \& Forman, E.H. (1991). An Analytic approach to Marketing Decisions. Prentice Hall, London.

Fitzsimmons, J.A, \& Fitzsimmons, M.J (2010). Service Management Operations, Strategy, Information Technology. McGraw-Hill, New York.

Güngör, Z., Serhadlıoğlu, G., \& Kesen, S. E. (2009). A fuzzy AHP approach to personnel selection problem. Applied Soft Computing, 9(2), 641-646.

Hogan, K. M., Olson, G.T., \& Sillup G.P. (2009). Helping the self insured company select the right pharmacy benefits manager (PBM)-An AHP based method. Research in Healthcare Financial Management, 12, 59-75.

Johnston, R. (1999). Service operations management: return to roots. International Journal of Operations and Production Management, 19(2), 104-124.

Johnston, R. (2005). Service operations management: from the roots up. International Journal of Operations and Production Management, 25(12), 1298-1308.

Juran, J.M., \& Godfrey, A.B. (1998). Juran's quality handbook. $5^{\text {th }}$ ed. McGraw-Hill, New York.

Machuca, J.A., González-Zamora, M., \& Aguilar-Escobar, V.G. (2007). Service Operations Management research. Journal of Operations Management, 26(1), 133-134.

Peniwati, K. (2007). Criteria for evaluating group decision-making methods. Mathematical and Computer Modelling, 46(7-8), 935-947.

Pilkington, A., \& Meredith, J. (2009). The evolution of the intellectual structure of operations management--1980-2006: A citation/co-citation analysis. Journal of Operations Management, 27(3), 185-202.

Rovinelli, \& R.J., Hambleton, R.K. (1977). On the use of content specialists in the assessment of criterion-referenced test item validity. Dutch Journal of Educational Research, 2, 49-60.

Russell, R, \&Taylor, B.W., (2011), Operations Management, Wiley, Alaska.

Saaty, T., (1980). The Analytic Hierarchy Process. McGraw-Hill, New York.

Slack, N., Chambers, S., \& Johnston, R. (2010). Operations Management. $6^{\text {th }}$ ed, Financial Times/Prentice Hall, Harlow.

Stevenson, W.J., \& Sum, C.C. (2010). Operations Management an Asian Perspective. McGraw-Hill, New York.

Schermerhorn, J.R. (2011). Introduction to Management. $11^{\text {th }}$ ed. John Wiley and Sons, Hoboken.

Tam, M.C., \& Tummala, V.M.R. (2001). An application of the AHP in vendor selection of a telecommunications system. The Internation Journal of Management Science, 29(2), 171-182.

Vaidya, O. S., \& Kumar, S. (2006). Analytic hierarchy process: An overview of applications. European Journal of Operational Research, 169(1), 1-29. 
Winston, W.L., \& Goldberg, G.B., (2004). Operations Research: Applications and Algorithms. $4^{\text {th }}$ ed. Duxbury Press, Boston.

Yaun, Y., \& Shaw, M.J. (1995). Induction of fuzzy decision trees. Fuzzy Sets and Systems, 69(2), $125-139$.

Xing, B., \& Zhang, A. (2006). Application of Fuzzy Analytical Hierarchy Process in Selecting a Project Manager. Management Science and Engineering, 2006 ICMSE '06. 2006 International Conference on, 1417-1421. 